\title{
NILAI KARAKTER TANGGUNG JAWAB DALAM SAJAK-SAJAK SUBAGIO SASTROWARDOYO
}

\author{
Sugeng Supriyono, Nugraheni Eko Wardani, dan Kundharu Saddhono \\ Pendidikan Bahasa Indonesia, Pascasarjana Univesitas Sebelas Maret \\ Jalan Ir. Sutami 36 A, Surakarta, Jawa Tengah \\ Surel: sugengsupriyonoo@gmail.com
}

Informasi Artikel:

Dikirim: 19 Juli 2018; Direvisi: 28 Juli 2018; Diterima: 31 Juli 2018

DOI: $10.26858 /$ retorika.v11i2.6370

RETORIKA: Jurnal Bahasa, Sastra dan Pengajarannya berada di bawah lisensi Creative Commons Attribution-NonCommercial 4.0 International License.

ISSN: 2614-2716 (cetak), ISSN: 2301-4768 (daring) http://ojs.unm.ac.id/retorika

\begin{abstract}
Character's Value Of Rerponsibilities from Subagio Sastrowardoyo Poems. The purpose of this study is to describe the value of responsibility character building of poems by Subagio Sastrowardoyo. This research includes descriptive qualitative research type with content analysis. Sources of data in this study book collection of Simfoni Dua by Subagio Sastrowardoyo. Techniques of collecting data using library techniques, refer method, and record. Data analysis technique uses interaction technique with stilistika approach. Based on the results of research that has been done, it is found that the value of responsibility character building are implicit in the words, phrases, and sentences, ncluding spiritual responsibility to God, social responsibility to fellow human beings, and pers onal responsibility to yourself. The value of responsibility character building that is contained in the poems of Subagio Sastrowardoyo is relevant to literary learning which includes the competence of knowledge and skills of appreciating and writing poetry.
\end{abstract}

Abstrak: Nilai Karakter Tanggung dalam Jawab Sajak-sajak Subagio Sastrowardoyo. Tujuan penelitian ini adalah mendeskripsikan nilai pendidikan karakter tanggung jawab sajak-sajak karya Subagio Sastrowardoyo. Penelitian ini termasuk jenis penelitian kualitatif deskriptif dengan analisis konten. Data bersumber dari buku kumpulan sajak Simfoni Dua karya Subagio Sastrowardoyo. Teknik pengumpulan data menggunakan teknik pustaka, simak, dan catat. Teknik analisis data menggunakan teknik interaktif dengan pendekatan stilistika. Berdasarkan hasil penelitian ditemukan nilai pendidikan karakter tanggung jawab yang tersirat dalam kata, frasa, dan kalimat, meliputi tanggung jawab spritual kepada Tuhan, tanggung jawab sosial kepada sesama manusia, dan tanggung jawab personal kepada diri sendiri. Nilai pendidikan karakter tanggung jawab yang terkandung dalam sajak-sajak Subagio Sastrowardoyo relevan dengan pembelajaran sastra, yakni kompetensi pengetahuan dan keterampilan mengapresiasi dan menulis puisi.

Kata kunci: pendidikan karakter, pembelajaran sastra, Simfoni Dua, tanggung jawab 
Pendidikan karakter merupakan kebutuhan yang sangat esensial dalam era teknologi dan informasi yang telah menembus batas-batas budaya antarbangsa. Derasnya arus budaya massa telah menggerus sendi-sendi berkehidupan masyarakat, utamanya generasi muda, termasuk di dalamnya peserta didik. Dampak yang ditimbulkan oleh perubahan itu adalah terjadinya pergeseran nilainilai etika moral yang jauh dari nilai-nilai budaya bangsa Indonesia yang bermartabat dan berkeadaban. Di satu sisi, kemajuan teknologi dan informasi memberikan manfaat positif, yaitu mudahnya mengakses berbagai informasi dan ilmu pengetahuan. Di sisi lain, dampak negatif yang timbul adalah lahirnya cara pandang dan berfikir yang instan, pragmatis, hedonistis, bahkan individualistis. Oleh sebab itu, dibutuhkan kemampuan dan kemauan yang kuat dari berbagai pihak untuk menumbuhkembangkan penguatan nilai-nilai pendidikan karakter.

Menyikapi permasalahan tersebut, pemerintah melalui Peraturan Presiden Nomor 87 tahun 2017 dan Peraturan Menteri Pendidikan dan Kebudayaan Nomor 23 tahun 2017 menegaskan dan mengatur tentang penguatan pendidikan karakter. Dalam Perpres tersebut dijelaskan bahwa yang disebut dengan Penguatan Pendidikan Karakter (PPK) adalah gerakan pendidikan di bawah tanggung jawab satuan pendidikan untuk memperkuat karakter peserta didik melalui harmonisasi olah hati, olah rasa, olah pikir, dan olah raga dengan pelibatan dan kerja sama antara satuan pendidikankeluarga, dan masyarakat sebagai bagian dari Gerakan Nasional Revolusi Mental (GNRM).

Pendidikan karakter diartikan sebagai upaya penanaman kecerdasan dalam berfikir, penghayatan dalam bentuk sikap, dan pengalaman dalam bentuk perilaku yang sesuai dengan nilai-nilai luhur yang menjadi jati diri peserta didik, diwujudkan dalam interaksi dengan Tuhan, diri sendiri, masyarakat dan lingkunganya (Zubaedi, 2011:17). Pendidikan karakter merupakan pendidikan budi pekerti plus yang melibatkan aspek pengetahuan, perasaan, dan tindakan (Licona, 2012:72).

Nilai karakter merupakan aspek utama dalam kehidupan abad ke-21 yang penting ditumbuhkembangkan melalui proses pembelajaran. Tantangan yang semakin kompetitif menempatkan nilai karakter sebagai faktor penting untuk berinteraksi, membangun jejaring, dan meraih sukses (Saleh dan Sultan, 2015:117). Salah satu cara menanamkan dan membentuk karakter peserta didik dalam konteks kelembagaan di sekolah adalah melalui pembelajaran sastra. Pembelajaran sastra yang berkaitan dengan penanaman nilai karakter tanggung jawab, meliputi tanggung jawab individu sebagai peserta didik, tanggung jawab sosial, dan tanggung jawab moral spritual.

Tanggung jawab adalah salah satu wujud nilai yang menjadi sasaran pendidikan karakter yang sedang digalakkan. Kementerian Pendidikan dan Kebudayaan (2010) merumuskan 18 butir nilai-nilai yang menjadi pijakan dalam pembentukan karakter peserta didik. Karakter tanggung jawab merupakan salah nilai yang menjadi sasaran. Nilai karakter tanggung jawab bermakna nilai, sikap, dan perilaku seseorang untuk melaksanakan tugas dan kewajibannya yang seharusnya dilakukan terhadap diri sendiri, masyarakat, lingkungan (alam, sosial, dan budaya), negara dan Tuhan Yang Maha Esa.

Ardianti (2017) menyatakan bahwa seorang peserta didik dapat ditanamkan karakter tanggung jawab jika terbiasa bertindak bertanggung jawab terutama kepada lingkungannya. Berkaitan dengan pembentukan karakter Furqon (2010:35) menjelaskan beberapa cara untuk menciptakan pembentukan karakter, yaitu dengan keteladanan, penanaman kedisiplinan, pembiasaan, menciptakan suasana kondusif, integrasi, dan internalisasi. Secara lebih terinci Siburian (2012) menjelaskan ada beberapa indikator dalam menanamkan karakter tanggung jawab, antara lain (1) perbuatan yang seharusnya dilakukan (2) merencanakan apa yang dilakukan kedepannya, (3) selalu mencoba melakukan sesuatu, (4) melakukan sesuatu sebaik mungkin, (5) mampu mengendalikan diri terhadap sesuatu, (6) mampu menerapkan disiplin yang baik, (7) berpikir dahulu sebelum melakukan sesuatu, (8) mampu menjadi teladan bagi semua orang, dan (9) bertanggungjawab terhadap semua perkataan, sikap, dan tindakan.

Karya sastra sangat bermanfaat sebagai wahana dan media pendidikan karakter karena di dalamnya terkandung substansi nilai-nilai kehidupan dari masa ke masa. Sebagai sarana pendidikan, karya sastra berperan dalam membentuk kepribadian yang harmonis, selaras antara budi dan karsa. Pembelajaran sastra bertujuan agar siswa memiliki kecerdasan intelektual, emosional, dan spiritual (Nuryatin dan Irawati, 2016: 2). Pembelajaran sastra bertugas sebagai sarana pewarisan sistem nilai yang merupakan sumber 
norma kedewasaan, bukan sistem nilai yag mewariskan ilmu pengetahuan (Harjono, 2012). Karya sastra membangun pemahaman dan pengertian antarbudaya yang berbeda yang membutuhkan kemampuan sikap tanggung jawab untuk menghormati dan penerima perbedaan. Sikap tanggung jawab merupakan esensi dari nilai-nilai pendidikan karakter yang wajib ditanamkan kepada peserta didik.

Pembelajaran sastra di sekolah menengah pada hakikatnya adalah upaya untuk membina etika dan kearifan manusia. Tujuan pokok pembelajaran sastra adalah untuk mencapai kemampuan apresiasi kreatif (Marni, 2016:26). Dengan memiliki kemampuan apresiasi sastra, peserta didik diharapkan mempunyai bekal untuk merespon kehidupan ini secara artistik imajinatif.

Puisi sebagai objek kajian penelitian merupakan bidang kajian yang memiliki nilai manfaat dan kelayakan. Salah satu karya puisi yang sederhana namun sarat dengan makna yang mendalam adalah sajak-sajak kumpulan puisi Simfoni Dua karya Subagio Sastrowadoyo. Subagio Sastrowardoyo merupakan salah seorang penyair Indonesia modern yang memperlihatkan perhatian yang cukup intens dan konsisten terhadap tematema tentang eksistensi kehidupan manusia. Selain dikenal sebagai penyair, Subagio Sastrowardoyo juga seorang cerpenis, esais, dan kritikus sastra.

Sajak-sajak Subagio dikenal mengandung filosofi yang tinggi, bahasa simbol, dan perumpamaan yang dipergunakan dipilih secara matang dan penuh kedewasaan. Sajak-sajak Subagio Sastrowardoyo memperlihatkan intensitas yang mengesankan. Simfoni Dua merupakan bukti betapa obsesif Subagio menggumuli tema-tema yang berkaitan dengan eksistensi hidup manusia. Latar inilah yang melandasi penulis untuk meneliti kumpulan puisi Simfoni Dua. Landasan kedua, didasari oleh aspek mekanik sajak-sajak Subagio Sastrowardoyo yang tidak rumit, dalam bingkai puisi bebas dengan pendayagunaan diksi, gaya bahasa, dan citraan yang segar, unik, dan variatif sebagai sarana retorika dan estetika karya seni bahasa. Karya Subagio Sastrowardoyo juga kental dengan nilai etis moral yang relevan sebagai pembelajaran sastra yang bermakna dan berdaya guna untuk peserta didik.

Beberapa penelitian terdahulu menunjukkan bahwa karya sastra memiliki nilai-nilai pendidikan karakter yang relevan dengan kebutuhan pembelajaran saat ini. Penelitian Irma (2018) yang menganalisis nilai-nilai pendidikan karakter dalam novel Ibuk karya Iwan Setiawan menemukan nilai pendidikan karakter yang meliputi; (1) hidup sederhana, (2) tanggung jawab, (3) kasih sayang, (4) berbakti pada orang tua, (5) religius, (6) peduli, (7) menghargai prestasi, (8) kerja keras, (9) cinta tanah air, (10) jujur, (11) empati, dan (12) gemar membaca. Berdasarkan temuan itu, Novel Ibuk yang dikaji layak dijadikan sebagai bahan ajar pembelajaran sastra di sekolah menengah karena mengandung banyak nilai pendidikan. Harjono (2012) yang mengkaji kumpulan puisi Chairil Anwar Aku Ini Binatang Jalang melalui pendekatan stilistika. Berdasarkan temuan hasil penelitian, terdapat nilai-nilai karakter religius, semangat kebangsaan, dan perasaan cinta yang perlu ditanamkan kepada siswa. Hasil penelitian tersebut memberi bukti bahwa karya sastra yang ditulis para pengarang Indonesia sarat nilai pendidikan karakter. Oleh karena itu, penulis menghipotesiskan bahwa sajak-sajak Subagio Sastrawardoyo memiliki kandungan nilai moral yang relevan untuk kehidupan masa kini dan masa depan.

Penelitian Aruna (2016) dalam kajian stilistika kumpulan puisi Melihat Api Bekerja karya M. Aan Mansyur menyimpulkan bahwa dari gaya bahasa perbandingan yang dipergunakan dalam puisi tersebut mengekspresikan perasaan cinta kasih yang relevan sebagai bahan pembelajaran pendidikan karakter peserta didik. Dwinuryani (2017), fokus penelitiannya adalah kajian pendidikan karakter berbasis kearifan lokal pada cerita rakyat. Berdasarkan hasil penelitian ditemukan sepuluh muatan nilai karakter pada cerita rakyat Nyi Andan Sari dan Ki Guru Soka yang relevan dipergunakan sebagai materi ajar dalam pelaksanaan pembelajaran pendidikan karakter di sekolah melalui media karya sastra. Penelitian ini berbeda dari objek kajian dibandingkan kedua penelitian tersebut.

Penelitian senada dilakukan Wardani dan Widyastuti (2013). Dari hasil penelitian tersebut disimpulkan bahwa penanaman nilai karakter pada peserta didik sangat efektif melalui pengembangan nilai-nilai budaya di sekolah termasuk simbol di dalamnya. Puisi kaya akan bahasa simbol, puisi juga merupakan warisan budaya dari para penyair yang dibesarkan oleh dunia pendidikan (sekolah) dengan beragam latar belakang sosial budaya yang melingkupinya. Penelitian-penelitian yang mengkaji tentang nilai pendidikan karakter di atas masih bersifat umum, se- 
dangkan penelitian penulis difokuskan kepada nilai pendidikan karakter tanggung jawab. Objek kajian penelitian memiliki ruang lingkup yang spesifik dibanding kajian sebelumnya.

Puisi merupakan karya sastra yang mengekspresikan pesan-pesan penulis dengan bahasa yang indah. Karakteristik tersebut memberi daya pikat bagi penanaman pendidikan karakter bagi pembaca. Hasil penelitian $\mathrm{Alex}, \mathrm{Li}$, dan Cao (2011) menyebutkan bahwa melalui analisis citraan dapat diketahui ciri khas karakteristik seorang penyair yang mengekspresikan karakter cinta kasih pada lirik lagu karya Liu Yong dan Shu Shi penyair pada era dinasti Song. Berkaitan dengan kajian nilai karakter dalam karya sastra melalui pendekatan stilistika dari unsur citraan, Khan (2016) menganalisis gaya bahasa pada puisi John Keats yang berjudul To Autmn menemukan bahwa pendayagunaan gaya bahasa dalam struktur puisi menjadikan puisi sebagai karya seni bahasa yang indah dan kaya makna. Keindahan dan kebermaknaan dimaksudkan penyair untuk mempengaruhi sifat dan perilaku pembaca terhadap karakter rasa cinta kasih sebagai cermin nilai kemanusiaan.

Penelitian ini bertujuan mengungkap nilainilai karakter tanggung jawab dalam kumpulan sajak Simfoni Dua karya Subagio Sastrowardoyo. Hasil penelitian diharapkan menjadi rujukan dalam penumbuhan karakter tanggung jawab peserta didik dan pembelajaran sastra di sekolah.

\section{METODE}

Penelitian ini termasuk jenis peneltian kualitatif deskriptif dengan analisis konten melalui pendekatan stilistika. Penelitian kualitatif adalah penelitian yang menghasilkan data deskriptif berupa kata-kata tertulis atau lisan dari orang-orang atau perilaku yang diamati (Moeleong, 2017:5). Sumber data primer dalam penelitian ini adalah buku Sajak-Sajak Subagio Sastrowardoyo Simfoni Dua, diterbitkan oleh Balai Pustaka, Jakarta, dengan nomor penerbitan 3770 cetakan kelima tahun 1999.

Data dalam penelitian ini adalah 3 judul sajak dalam Simfoni Dua yaitu, sajak Rasa Dosa, Lamunan Aborijin, dan Motif II. Dalam penelitian ini data sekunder berupa tulisan-tulisan atau tinjauan kritis terhadap karya-karya puisi Subagio Sastrawardoyo. Selain itu, tulisan-tulisan yang menceritakan riwayat hidup Subagio Sastrowar- doyo, latar belakang sosial budaya yang melingkupinya, beserta zaman dan lingkungan tempatnya berpijak dapat dianggap sebagai data sekunder.Teknik pengumpulan data dalam penelitian ini, meliputi teknik pustaka, simak, dan catat. Adapun keabsahan data dilakukan dengan triangulasi metode, sedangkan teknik analisis data menggunakan prosedur analisis data interaktif, yaitu reduksi data, penyajian data, dan penarikan simpulan (Miles dan Huberman, 2009:20).

\section{HASIL PENELITIAN DAN PEMBAHASAN}

\section{Hasil}

Bertolak dari tujuan dan metode penelitian, pada bagian ini disajikan hasil penelitian berupa analisis nilai pendidikan karakter tanggung jawab yang terkandung dalam kumpulan puisi Simfoni Dua karya Subagio Sastrwardoyo. Sajian hasil penelitian ini meliputi deskripsi penggunaan bahasa dalam tataran kata, frasa, dan kalimat yang merujuk pada makna sebagai pesan nilai pendidikan karakter tanggung jawab yang terkandung dalam kumpulan puisi Simfoni Dua. Sajian hasil penelitian ini dipaparkan sebagai berikut.

\section{Tanggung Jawab Spitual kepada Tuhan}

Sebagai makluk ciptaan Tuhan, manusia memiliki tanggung jawab kepada sang pencipta. Segala perkataan dan perbuatan manusia semasa hidup di dunia harus dipertanggungjawabkan di hadapan Tuhan. Setiap kebajikan akan mendapatkan imbalan sedang setiap keburukan atau kesalahan akan mendapatkan hukuman. Tanggung jawab ini bersifat transendental yang tidak dapat dilimpahkan kepada orang lain. Bentuk tanggung jawab ini dilukiskan Subagio Sastrowardoyo dalam sajak Rasa Dosa.

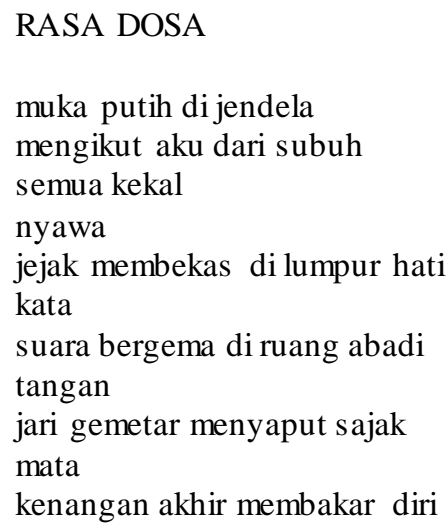


muka putih di jendela

mengikut aku dari subuh

tanganku lumpuh

(Sastrowardoyo, 1999: 26)

Pada sajak Rasa Dosa, kata putih bermakna suci atau bersih, ungkapan /muka putih/ menunjuk kepada sesuatu yang suci, murni, sejati, dan bersih. Muka putih melambangkan Tuhan atau malaikat yang hanya dapat dilihat dengan mata hati. Hal ini terlihat dengan jelas ketika kata muka puth yang diikuti kemudian dengan kata /jendela/ sebagai simbol dari hati manusia. Pada frasa muka putih di jendela dalam baris ke-1 bait ke-1 sajak di atas bermakna Tuhan selalu ada di hati si aku lirik. Diksi /mengikut/ bermakna menghantui atau selalu terlintas, sedang kata /subuh/ bermakna awal dari kehidupan. Kata /kekal/ mempertajam muka putih yang terlihat dari hati yang bersifat abadi. Frasa mengikut aku dari subuh dalam baris kedua bermakna selalu menghantui atau membayangi si aku lirik dalam mengawali setiap kehidupan.

Bait pertama sajak Rasa Dosa mengandung makna bahwa di dalam lubuk hati yang paling dalam, si aku selalu merasakan bahwa di dalam dirinya Tuhan selalu hadir dan selalu memberikan peringatan terhadap segala dosa dan kesalahan yang telah diperbuatnya. Kesalahan itu selalu mewarnai setiap langkahnya dalan kehidupan sehari-hari. Kata kekal pada baris ketiga bermakna bahwa Tuhan bersifat kekal yang tidak dimiliki makhluk lain.

Diksi /nyawa/ bermakna kehidupan, dalam kehidupan manusia telah melakukan banyak dosa yang diungkapkan penyair dengan kata /lumpur hatil, hati yang penuh dengan kesalahan dan dosa yang selalu membekas. Kata hati selalu bergema di /ruang abadi/ yang mengandung makna relung hati atau hati yang terdalam. Bait ke-3 dan ke-4 sajak ini bermakna bahwa Tuhan selalu hadir dalam setiap kehidupan Si Aku yang selalu mengusik hatinya, dan suaranya selalu mengingatkan setiap perbuatan dosa Si Aku.

Kata /tangan/ sebagai simbol perbuatan manusia. Dengan tangan, manusia telah banyak melakukan tindakan dosa. Jari-jari tangan pun turut menjadi saksi perbuatan itu yang tak mungkin bisa dihapus, yang dilukiskan dengan frasa /jari gemetar menyaput sajak/. Diksi/mata/ bermakna cahaya Tuhan, Tuhan selalu menerangi hati Si Aku dengan peringatan atas segala perbuatan dosanya, cahaya Tuhan juga akan mampu menyadarkan Si Aku yang diungkapkan dengan kata /membakar diri/. Peringatan Tuhan melalui hati nurani Si Aku selalu hadir dalam setiap kehidupannya, rasa dosa Si Aku akan selalu mengikutinya hingga Si Aku tak mampu berbuat yang bertentangan dengan hati nuraninya, yang dilukiskan penyair dengan diksi /tanganku lumpuh/.

Sajak Rasa Dosa di atas menggambarkan Si Aku sebagai manusia melekat dalam dirinya sebauh tanggung jawab. Frasa muka putih di jendela bermakna Tuhan yang selalu ada dalam pikirannya. Tuhan atau malaikat yang kekal akan selalu mengawasi dan mencatat setiap perbutan $\mathrm{Si}$ Aku. Frasa yang dikemas dengan citraan gerak ini menegaskan bahwa sepanjang dimulainya kehidupan hingga akhir hidup manusia selalu terkait dan terikat oleh tanggung jawab kepada Tuhan. Larik-larik sajak pada data bait ke-1 dari judul sajak Rasa Dosa dipertegas maknanya pada bait ke-2. Hal yang harus dipertanggungjawabkan manusia dalam hidup, meliputi perkataan (kata), perbuatan (tangan), dan penglihatan (mata). Semua yang dikatakan, diperbuat, dan dilihat akan dimintai pertanggungjawaban oleh Tuhan.

\section{Tanggung Jawab Sosial kepada Sesama Ma- nusia}

Tanggung jawab manusia kepada sesamanya merupakan wujud tanggung jawab sosial yang bersifat horisontal. Tanggung jawab ini merupakan tugas manusia hidup di muka bumi. Sesuai dengan kodratnya, manusia diciptakan sebagai makluk sosial akan selalu berinteraksi dengan manusia lain. Manusia tidak dapat hidup sendiri tanpa kehadiran manusia yang lain. Relasi ini dibangun atas dasar persamaan hak dan kedudukan manusia tanpa membedakan suku, agama, bahasa, bangsa, dan ras. Bentuk tanggung jawab ini diilustrasikan Subagio Sastrowardoyo dalam sajak Lamunan Aborijin.

\section{LAMUNAN ABORIJIN}

Masa lalu adalah panas terik di padang pasir dan berkelana di zaman mimpi tak bertepi.

Masa kini adalah berkeliaran di pinggir kota dan melupakan diri dalam bir dan weski

Masa depan adalah malam yang panjang tanpa setitik cahaya di langit kelam. Tak ada harapan.

Aku tak berani lagi menepuk dada 
dan menunjuk diri: inilah aku!

Seperti hantu aku menyelinap di semak

belukar dan menari dekat api upacara.

Aku melepaskan dendam di buluh perindu.

Ular keramat menggeliat di bukit karang.

Kisah pembrontakannya kugurat di kulit kayu.

Aku bakal merdeka di tanah moyang.

(Sastrowardoyo, 1999:56)

Pada sajak Lamunan Aborijin, penulis menggambarkan keinginan atau harapan si Aborigin sebagai salah satu suku bangsa yang ditetapkan Tuhan. Frasa /panas terik di padang/merupakan bentuk citraan perabaan yang menggambarkan penderitaan si Aborigin. Frasa /di zaman mimpi tak bertepi/ bermakna harapan yang jauh dari kenyataan dan tanpa kejelasan kapan akan menjadi kenyataan. Bait pertama secara keseluruhan menggambarkan masa lalu suku Aborigin yang berjuang keras untuk membangun tempat tingal sebagai sebuah suku.

Bait kedua melukiskan keadaan masa kini setelah hak-haknya terampas oleh bangsa pendatang. Masa kini, suku Aborigin terlantar di pinggir-pinggir kota. Frasa /melupakan diri dalam bir dan weski/wujud citraan pencecapan yang menggambarkan keadaan psikologis suku Aborigin yang frustasi. Pada bait ketiga, tampak dengan jelas penyair sebagai pengujar menggambarkan sebuah situasi kesedihan yang mendalam. Penggunaan metafora /masa depan adalah malam yang panjang/ yang dipertautkan dengan citraan visual Itanpa setitik cahaya dilangit kelam/ semakin mempertegas keadaan duka nestapa si Aborigin yang tanpa harapan.

Pada bait keempat, si aku Aborigin digambarkan telah kehilangan identitas dirinya dan hak-haknya sebagai bangsa. Penggunaan majas simile yang dikemas dengan kombinasi citaan gerakan pada frasa /seperti hantu aku menyelinap di semak belukar dan menari dekat upacara/ mengesankan efek ketakutan yang luar biasa bagi Aborigin. Ia telah kehilangan kemerdekaan dan kedaulatan hakiki sebagai manusia yang bebas dari rasa takut terhadap sesamanya.

Pada bait kelima, menjelaskan latar suasana marah, kecewa, benci, dan dendam yang hanya dapat dikisahkan pada leluhurnya. Frasa /ular keramat menggeliat di bukit karang/ adalah bentuk personifikasi dari bangsa pemberontak yang angkuh, arogan, egois, sadis, dan kejam. Keputusasaan Si Aku hanya dapat menghibur dirinya sindiri akan terbebas dari ancaman dan ketidak- adilan di tanah moyang, yang artinya setelah si Aku mati.

Secara keseluruhan, aspek-aspek kebahasaan yang mencakup pilihan kata, gaya bahasa, dan citraan dalam sajak Lamunan Aborijin menyiratkan makna penderitaan dan ketakutan yang berkepanjangan manusia sebagai suku bangsa yang terjajah, terusir, dan tertindas. Tanggung jawab manusia hidup di bumi adalah selalu berbuat kebaikan terhadap sesama. Manusia memiliki tanggung jawab mutlak untuk memelihara perdamaian di dunia agar kehidupan menjadi indah. Isi sajak Lamunan Aborijin merupakan bentuk peringatan si penyair kepada pembaca bahwa eksistensi hidup manusia harus bersedia dan sanggup memiliki sikap tanggung jawab menerima perbedaan.

Penyair hendak memberikan pesan bahwa manusia tidak memiliki hak untuk menindas sesamanya. Ketika penindasan, kedzholiman terjadi maka sesengguhnya manusia telah melalaikan tanggung jawabnya. Sajak di atas juga merupakan satire bagi bangsa Australia, bangsa suku Aborigin berada. Tanggung jawab negara haruslah melindungi setiap warganya tanpa membedakan perbedaan suku, ras, agama, dan bahasa. $\mathrm{Pa}$ da sajak di atas tampak dengan jelas bahwa si aku pengujar memiliki hasrat yang besar sebagai bagian dari warga dunia yang bertanggungjawab untuk menciptakan perdamaian abadi. Isi puisi secara keseluruhan mengajarkan pentingnya tanggung jawab sosial kepada sesama manusia.

\section{Tanggung Jawab Personal kepada Diri Sendiri}

Tanggung jawab kepada diri sendiri merupakan bentuk tanggung jawab yang paling dasar. Setiap manusia dilahirkan sebagai makluk individu mempunyai otoritas untuk menentukan masa depannya sendiri. Tanggung jawab diri dilakukan dengan membangun kualitas diri baik secara jasmani maupun rohani. Kualitas diri dibangun atas dasar prinsip-prinsip hidup dan introspeksi diri. Ketika individu manusia tidak mampu menolong manusia lain, setidaknya manusia harus mampu menolong dirinya sendiri. Tuhan tidaklah akan merubah nasib seseorang kecuali ia mengubahnya sendiri.

Bentuk tanggung jawab ini menjadi sangat penting karena tidak semua urusan manusia bisa dibebankan atau ditugaskan kepada orang lain. Kompetensi diri sangat dibutuhkan dalam kerangka menuju cita-cita setiap individu manusia, 
hidup bahagia lahir dan batin, dunia dan akhirat. Dengan ungkapan lain, tanggung jawab kepada diri sendiri adalah sikap hidup mandiri tanpa terlalu bergantung kepada orang lain. Wujud tanggung jawab ini perlu secara terus menerus ditanamkan kepada peserta didik. Berikut ini adalah gambaran tanggung jawab manusia kepada dirinya sendiri dalam sajak Motif II.

\section{MOTIF II}

Siapa yang mencipta lagu ini

Yang mengisi ruang-ruang tak Berhuni?

Aku tak terlambat hadir dan

Masih sempat mendengarnya

Di waktu senja sebelim gelap tiba.

Nada-nada lembut mendambakan hidup

Murni, tulus, dan kalis dari dosa.

Seperti bunyi suling, gender, dan

Rebab yang menyentuh sanubari.

Kesepian harus diterima sebagai

nasib yang tersurat. Biduan menghimbau

aku: Ya mas, ya mas, ingat, ya mas.

Aku yang gelisah terguncang dari

kenanaran. Bukankah hanya manusia

susila yang selamat sampai ke sorga?

Condrolukito! Jangan terus dendangkan

gending megatruh.

Karena tak tahan malu aku tutup telingaku.

(Sastrowardoyo, 1999:58)

Mencermati judul sajak Motif II, kata /motifl dapat diartikan sebagai bentuk, corak, atau warna. Motif juga berhomonimi dengan makna maksud atau tujuan. Sebagaimana sifat bahasa puisi yang padat kata dan makna, kehadiran setiap karya puisi selalu dikontrol oleh manipulasi bahasa penyair. Pada bait pertama sajak Motif II menggambarkan latar suasana yang dialami $\mathrm{Si}$ Aku lirik. Frasa/ruang-ruang tak berhuni/ melukiskan rasa kesepian yang dialami Si Aku lirik. Bait kedua, menjelaskan suasana sepi tersebut dengan kalimat Aku tak terlambat hadir dan masih sempat mendengarnya diwaktu senja sebelum gelap tiba yang terbagi kedalam tiga baris.

Kalimat tersebut melukiskan bahwa Si Aku lirik sebagai individu merasa belum cukup ilmu pengetahuan untuk menuju kebahagiaan diri. Bagi Si Aku, lirik mencari ilmu pengetahuan untuk bekal diri merupakan bentuk tanggung jawab terhadap dirinya sendiri yang tak mengenal batas waktu. Diksi /diwaktu senja/ dan /sebelum gelap tiba/ merupakan bentuk diksi konotatif yang bermakna, di masa tua sebelum mati atau ajal men- jemput. Pada bait ini, penyair menggambarkan kesunyian yang dialaminya di masa tua. Masa akan dirasakan setiap manusia, ketika antara fisik dan keinginan sudah tak seimbang. Ketika tanggung jawab di dunia telah dirasa terselesaikan, ketika aktifitas tak lagi produktif, dan ketika raga sudah mulai lemah, kesepian itu datang mendera. Ada yang selalu dirasakan masih kurang, keinginan yang belum terpenuhi, bahkan kosong, yang dilukiskan dengan frasa konotatif /ruang tak berhunil.

Penyair hendak menyampaikan pesan bahwa setiap manusia pada saat tertentu harus mampu menolong dirinya sendiri. Penyair mengungkapkan perasaan hatinya kala waktu senja telah tiba. Di usia senja penyair mendambakan kedamaian hati, ketentraman batin, dan kebahagiaan. Untuk mendapatkan itu, manusia tidak dapat meminta kepada manusia lain atau sekadar berdoa kepada Tuhan. Kebahagian setiap individu manusia menjadi tanggung jawab dirinya sendiri. Kebahagian tidak dapat diminta tetapi harus diciptakan oleh individu manusia itu sendiri. Hal ini tampak dengan jelas digambarkan pada bait ketiga pada frasa /nada-nada lembut mendambakan hidup/. Nada yang lembut mendambakan hidup itu adalah hidup yang murni, tulus, dan kalis dari dosa. Nada-nada itu disimbolkan dalam bunyi suling, gender, dan rebab. Penyair seoalah ingin menyampaikan pesan kepada pembaca bahwa setiap manusia memiliki keinginan yang sama, yaitu hidup penuh kedamaian. Nada-nada yang keluar dari bunyi /suling/,/gender/, dan /rebab/ (alat gamelan Jawa) dipergunakan sebagai simbol oleh penyair. Ketiga alat gamelan Jawa itu menyiratkan pesan bahwa ketika manusia sudah di ujung senja (usia tua) maka harus memperbanyak doa, dzikir, dan taubat. Ketiga alat musik gamelan Jawa itu melantunkan bunyi yang lembut, yang bermakna penuh kepasrahan.

Bait keempat dan kelima melukiskan suasana batin si aku lirik yang gelisah, yang kemudian terguncang dari kenanaran. Si Aku sebagai manusia merasa masih banyak dosa yang hanya dirinya sendiri yang mampu menghapusnya. Si Aku merasa bahwa hanya manusia susila yang berhak atas kedamaian abadi. Hal ini tersirat pada frasa /bukankah hanya manusia susila yang selamat sampai ke surga?/

Penggunaan kata nama diri /Condrolukita/ dimaksudkan untuk membangun keterpaduan bentuk dan makna antara gamelan Jawa dan Condrolukito sebagai biduan. Adapun gendhing me- 
gatruh merupakan salah satu nama tembang macapat Jawa. Diksi /megatruh/ berasal dari kata bahasa Jawa pegat (putus) dan ruh (jiwa, sukma, atau nyawa).

Secara keseluruhan, isi dari sajak Motif II berbicara tentang tanggung jawab individu manusia terhadap dirinya sendiri. Manusia harus sanggup menerima kenyataan saat usia senja kesepian mendera. Sajak yang dikemas sarat dengan retorika dengan balutan estetika bahasa ini mengandung pesan yang sangat mendalam bahwa ketika usia senja tiba diambang kematian, setiap manusia mempunyai tanggung jawab pada dirinya sendiri untuk melakukan katarsis jiwa (pembasuhan jiwa).

\section{Pembahasan}

Secara keseluruhan, ketiga sajak dalam Simfoni Dua karya Subagio Sastrowardoyo dalam penelitian ini ditemukan nilai pendidikan karakter tanggung jawab. Hasil temuan ini berupa kata, frasa, dan kalimat yang bermakna pada muatan karakter tanggung jawab. Di samping itu tema dan amanat yang disampaikan penyair kepada pembaca berisikan tentang nilai tanggung jawab atas eksistensi hidup manusia yang bersifat transendental horisontal. Temuan ini menunjukkan bahwa sajak-sajak Simfoni Dua sarat dengan muatan pesan nilai etis moral. Nilai pendidikan karakter tanggung jawab dalam puisi Lamunan Aborijin, Motif II, dan Maut diungkapkan penyair secara tersirat melalui baris-baris sajak dalam bangun kumpulan puisi Simfoni Dua.

Nilai pendidikan karakter tanggung jawab yang terdapat dalam kumpulan puisi Simfoni Dua diharapkan dapat dijadikan sebagai bahan perenungan, dan penghayatan baik bagi pembelajar dan guru, selanjutnya diaplikasikan dalam pembelajaran sastra di kelas maupun diterapkan dalam perilaku sehari-hari di masyarakat. Sesuai dengan tujuan pendidikan nasional sebagaimana ditetapkan dalam UU RI Nomor 20 tahun 2003, seperti telah diuraikan pada bagian sebelumnya, maka pembelajaran sastra harus diimplementasikan dan diaplikasikan secara tepat, dengan pemilihan materi ajar sastra yang tepat dan berdaya guna.

Nilai pendidikan karakter tanggung jawab yang terdapat dalam sajak-sajak Subagio Sastrowardoyo relevan dengan dengan pembelajaran sastra di sekolah menengah. Karakter tanggung jawab perlu ditanamkan secara terus menerus kepada siswa. Materi ajar sastra paling potensial untuk penanaman nilai ini, melalui apresiasi dan ekspresi puisi, di samping diskusi kelas yang segar dengan belajar mempertanggungjawabkan hasil karyanya melalui tanya jawab dalam diskusi kelas. Kumpulan puisi Simfoni Dua juga sarat dengan balutan pesan moral yang menyiratkan nilai pendidikan karakter tanggung jawab siswa kepada Tuhan dan kepada orang lain.

Cara pembelajaran dan materi ajar sastra yang tepat dan berkesinambungan turut membentuk kepribadian siswa. Siswa yang terbiasa menggauli sastra, lebih dapat bersosialisasi, peka terhadap lingkungan, dan memiliki rasa tanggung jawab. Hal ini dikarenakan sastra tidak hanya berbicara tentang diri sendiri, tetapi juga berkaitan dengan tuhan, alam semesta, masyarakat, yang mampu mengungkap banyak hal dari berbagai segi. Sastra dapat menanamkan, menumbuhkan, dan mengembangkan norma-norma manusiawi membentuk karakter siswa yang baik, sehingga sastra memiliki peran yang penting dalam membangun perkembangan moral, sosial dan psikologi siswa. Hal ini sejalan dengan pernyataan Saryono (2009) yang mengemukakan bahwa genre sastra yang dapat dijadikan sarana untuk membentuk karakter bangsa, antara lain, genre sastra yang mengandung nilai atau aspek (1) literer-estetis, (2) humanistis, (3) etis dan moral, dan (4) religius-sufistis-profetis. Sajak-sajak Subagio Sastrowardoyo dalam kumpulan puisi Simfoni Dua memenuhi aspek-aspek tersebut.

Dengan pembelajaran dan pemilihan materi ajar sastra sastra yang tepat dan berdaya guna diharapkan dapat berkorelasi positif dengan perkembangan akademik siswa. Hal ini selaras dengan hasil penelitian yang dilakukan Benninga, Berkowitz, Kuehn, dan Smith (2003) yang dilakukan dengan melibatkan 681 sekolah di California menemukan bahwa, sekolah dengan totalitas yang lebih tinggi dalam mengimplementasikan pendidikan karakter memperoleh prestasi akademik lebih tinggi. Senada dengan Benninga dkk, penelitian yang dilakukan Larson (2009) menyatakan bahwa penanaman nilai karakter melalui sekolah berdampak terhadap kepedulian, tanggung jawab, dan sikap hormat peserta didik terhadap orang lain.

Secara teoretis hasil penelitian ini berimplikasi terhadap pengkajian dan perkembangan teori sastra, khususnya teori stilistika yang dapat dipergunakan untuk mengupas secara tuntas makna dari sebuah karya sastra berupa nilai-nilai ka- 
rakter di dalamnya. Para pembelajar sastra, pembaca dan pecinta puisi serta penyair-penyair muda memperoleh kemanfaatan dari hasil penelitian ini melalui tambahan pengetahuan dan pengalam baru sehubungan dengan mekanik sajak-sajak Simfoni Dua yang sederhana tetapi memikat karena penggunaan katanya yang unik segar, menarik dan penuh dengan nuansa pesan moral. Penelitian ini akan memperkaya penelitian di bidang sastra, lebih khusus penelitian karya sastra dengan pendekatan stilistika pada puisi. Penelitian ini juga akan membawa implikasi teoritis terhadap penelitian nilai pendidikan karakter dalam karya sastra.

Hasil penelitian sajak-sajak kumpulan puisi Simfoni Dua karya Subagio Sastrowardoyo dapat dijadikan sebagai materi pembelajaran sastra di SMA. Aspek-aspek stilistika dan nilai pendidikan karakter tanggung jawab di dalamnya dapat memotivasi siswa dalam pembelajaran apresiasi sastra. Sebagai materi ajar sastra di SMA, kumpulan puisi Simfoni Dua sangatlah menarik. Corak sajak-sajak Simfoni Dua yang sederhana dalam bingkai puisi bebas tidak terlalu sulit untuk dipahami siswa melalui kajian stilistika.

Pemberlakuan kurikulum 2013 di SMA mendasarkan pembelajaran bahasa Indonesia pada satuan kebahasaan berbasis teks. Implikasi yang timbul, pembelajaran bahasa dan sastra Indonesia di SMA sering banyak mengalami kesulitan. Kesulitan itu mencakup (a) pemilihan materi ajar, (b) kurang adanya minat kesastraan siswa, (c) kurangnya kreativitas guru, (d) kurangnya ketajaman apresiasi guru. Hasil temuan kajian nilai pendidikan karakter tanggung jawab terhadap sajak-sajak Subagio Sastrowardoyo dalam kumpulan puisi Simfoni Dua dengan pendekatan stilistika dapat dijadikan sebagai pilihan materi ajar puisi dalam pembelajaran sastra di SMA. Pemilihan materi ajar sastra dan pembelajarannya yang mendasarkan pada temuan kajian ini, yang berkaitan dengan kandungan nilai karakter tanggung jawab yang tersirat dalam bentuk keunikan kata, frasa, dan kalimat yang puitis dan ritmis, gaya bahasa dan citraan yang unik maka perlu disajikan secara proposional.

Nilai pendidikan karakter tanggung jawab merupakan salah satu muatan nilai pendidikan karakter dalam Simfoni Dua. Penanaman nilainilai karakter melalui pembelajaran sastra hendaknya disajikan secara profesional. Selama ini materi pembelajaran sastra di sekolah mengesankan sebagai pembelajaran nilai-nilai etika, se- mentara kajian stlistika bertumpu pada keindahan penggunaan bahasa, makna dan fungsinya dalam karya sastra. Implikasi dari hasil temuan dalam penelitian ini yang perlu ditekankan adalah bahwa hakikat karya sastra adalah karya estetika dan bukan karya etika. Atas dasar itu, pembelajaran sastra pada materi ajar menulis puisi hendaknya guru memberikan rambu-rambu pada siswa agar dalam menulis puisi tetap berpegang pada aspekaspek stilistika. Pesan moral yang akan disampaikan oleh siswa dalam karya puisinya harus dibalut dengan keindahan bahasa sesuai dengan konvensi sastra sehingga tidak terkesan sebagai karya etika yang jauh dari nilai-nilai keindahan sebagai karya sastra.

Berkenaan dengan sajak-sajak Simfoni Dua karya Subagio Sastrowardoyo relevansinya sebagai materi ajar sastra di SMA, guru dan siswa dapat mengambil nilai-nilai positif dari pesan moral di dalamnya maupun keunggulan mekanik sajaksajak Simfoni Dua sebagai kekhasan puisinya. Simfoni Dua hadir dan turut mewarnai puisi-puisi Indonesia modern dengan berbagai jenis dan diciptakan dengan latar sosial yang berbeda dengan latar sosial siswa bahkan latar sosial guru saat ini. Namun demikian, pesan-pesan moral atau nilainilai pendidikan karakter terutama nilai pendidikan karakter tanggung jawab perlu untuk dijadikan sebagai bahan perenungan dan penghayatan untuk selanjutnya dapat diimplementasikan dalam kehidupan sehari-hari di lingkungan masyarakat.

Hasil temuan kajian ini secara menyeluruh dapat dijadikan media dan wahana bagi siswa untuk mengasah keterampilan menalar, mengolah, dan menyajikan teks puisi secara efektif, kreatif, produktif, kolaboratif, kritis, mandiri, komunikatif, dan solutif. Dengan keterampilan ini maka tujuan pembelajaran pendidikan karakter melalui karya sastra yang mencakup kompetensi sikap spiritual, sikap sosial, pengetahuan, dan keterampilan akan terwujud.

Temuan hasil kajian ini dapat bermanfaat bagi siswa, guru dan pembaca sastra maupun peneliti selanjutnya. Siswa dapat mengambil manfaat dari temuan kajian berupa unsur-unsur stilistika dalam Simfoni Dua dengan berbagai kekhasan bahasa dan keunikannya sebagai sarana pembelajaran. Guru dapat membuka dan menambah kualitas akademiknya untuk menentukan materi ajar sastra yang sesuai dengan kebutuhan siswa. Pembaca dan penikmat sastra dapat menambah pengetahuan dan kecintaannya pada dunia sastra. 


\section{SIMPULAN}

Berdasarkan hasil penelitian dan pembahasan dapat ditarik simpulan sebagai berikut. Nilai pendidikan karakter tanggung jawab yang tersirat dalam sajak Subagio Sastrowardoyo mencakup tanggung jawab spiritual kepada Tuhan, tanggung jawab sosial kepada sesama manusia, dan tanggung jawab personal kepada diri sendiri. Temuan ini menunjukkan bahwa sajak-sajak Simfoni Dua sarat dengan muatan pesan nilai etis moral. Nilai pendidikan karakter tanggung jawab yang terdapat dalam kumpulan puisi Simfoni Dua diharapkan dapat dijadikan sebagai bahan perenungan, dan penghayatan baik di kelas maupun di masyarakat.

\section{DAFTAR PUSTAKA}

Abidin, Y. 2012. Pembelajaran Membaca Berbasis Pendidikan Karakter. Bandung: Refika Aditama.

Alex, C. F., Li, W. Y., \& Cao, J.. 2011. In Search of Poetic Discourse of Classical Chinese Poetry: An Imagery Based Stylistic Analysis of Liu Yang and Su Shi. Journal of Linguistics and Language Behavior, 2(2): 27-34.

Aminuddin. 1995. Stilistika: Pengantar Memahami Bahasa dalam Karya Sastra. Semarang: IKIP Semarang Press.

Ardianti, S. D., S. Wanabuliandari, dan S. Rahardjo. 2017. Peningkatan Perilaku Peduli Lingkungan dan Tanggung Jawab Sis wa melalui Model EJAS dengan Pendekatan Science Edutainment. Jurnal Pendidikan Dasar, 4 (1):1-7.

Aruna, L. 2016. Gaya Bahasa Perbandingan da-lam Kumpulan Puisi Melihat Api Bekerja Karya M. Aan Mansyur. Gramatika: Jurnal Penelitian Pendidikan Bahasa dan Sastra Indonesia, 2 (2):146-163.

Benninga, J. S., Berkowitz, M. W. Kuehn, P., dan Smith, K. 2003. The Relation of Character Education Implementation and Academic Achievement in Elementary Schools. Journal of Research in Character Education, 1(1):19-32.

Dwinuryati, Yustina, dan Andayani. 2017. Kajian Pen-didikan Karakter Berbas is Kearifan Lokal Pada Cerita Rakyat Nyi Andan Sari dan Ki Guru Soka. Jurnal Artefak, 4 (1):15-22.

Endraswara, S. 2013. Teori Kritik Sastra, Prinsip, Falsafah, dan Penerapan. Yogyakarta: CAPS.

Harjono, N. 2012. Kajian Stilistika Puisi-puisi Chairil Anwar sebagai Sarana Pembelajaran Apresiasi Sastra. Scholaria: Jurnal Pendidikan dan Kebudayaan, 2(1):22-38.
Teks puisi Simfoni Dua relevan dengan materi pembelajaran sastra di SMA sesuai dengan tuntutan kurikulum 2013, yaitu pembelajaran Bahasa Indonesia yang berbasis teks. Kumpulan puisi Simfoni Dua mempunyai potensi dan peran sebagai wahana dan media penanaman nilai pendidikan karakter tanggung jawab kepada peserta didik karena kental dengan nilai etika moral.

\section{UCAPAN TERIMA KASIH}

Penulis menyampaikan ucapan terima kasih kepada mitra bestari (reviewers) yang telah memberikan saran, kritik, dan rekomendasi untuk perbaikan artikel ini.

Ilahi, M. T. 2014. Gagalnya Pendidikan Karakter. Yogyakarta: Ar-Ruz Media.

Irma, C. N. 2018. Nilai-Nilai Pendidikan Karakter dalam Novel Ibuk Karya Iwan Setiawan. Retorika: Jurnal Bahasa, Sastra, dan Pengajarannya, 11 (1): 14-22.

Kasim, M. 2012. Sosialisasi Kurikulum 2013 di Sulawesi Selatan.Bahan Presentasi Sosialisasi Kurikulum 2012 yang di Sampaikan pada Tanggal 8-9 Februari 2012 di Makassar.

Kesuma, dkk. 2012. Pendidikan Karakter Kajian Teori dan Praktik di Sekolah. Bandung: Remaja Rosdakarya.

Khan, A. B. dan T. Jabeen. 2016. Stylistics Analys is of The Poem 'To Autumn' By John Keats. International Journal of Academic Research, 3(1): 127-137.

Larson, K. 2009. Understanding the Importance of Character Education.Tesis. Wisconsin: The Graduate School University of WisconsinStout.

Lickona, T. 2008. Pendidikan Karakter Panduan Mendidik Siswa Menjadi Pintar dan Baik. Bandung: Nusa Media.

Marni, S. 2016. Analis is Makna Intensi pada Puisi-Puisi Penyair Pemula: Analisis Puisi Karya Siswa SMAN Agam Cendekia. Gramatika. Jurnal Penelitian Pendidikan Bahasa dan Sastra Indonesia, 2(1): 25-32.

Miles, M. B. and Huberman, A.M. 1993. Qualitative Data Analysis: A Sourcebook of New Methods. London: Sage Publication Inc.

Moleong, Loxy J. 2017. Metodologi Penelitian Kualitatif. Bandung: Remaja Karya. 
Nuryatin, A., Irawati, R. Purnomo. 2016. Pembelajaran Menulis Cerpen.Semarang: Cipta Prima Nusantara.

Peraturan Menteri Pendidikan dan Kebudayaan Nomor 22 Tahun 2016 tentang Standar Proses Pendidikan Dasar dan Menengah.

Peraturan Presiden Nomor 87 Tahun 2017 tentang Penguatan Pendidikan Karakter Dengan Rahmat Tuhan Yang Maha Esa.

Pradopo, Rahmat Joko. 2014. Pengkajian Puisi. Yogyakarta: Gajah Mada University Press.

Saleh, M. dan Sultan. 2015. Pengembangan Bahan Ajar Bahasa Indonesia Berbasis Kurikulum 2013 yang Mengintegrasikan Karakter Bangsa di SMP. Pendidikan dan Pembelajaran, 22(2): 117-129.

Saryono. 2009. Pengantar Apresiasi Sastra. Malang: Universitas Negeri.

Sastrowardoyo, S. 1982. Catatan Tentang Simphoni. Jakarta: Gramedia
Sastrowardoyo, S. 1999. Simfoni Dua: Sajak-Sajak Subagio Sastrowardoyo. Jakarta: Balai Pustaka Siburian, P. 2012. Penanaman dan Implementasi Nilai Karakter Tanggung Jawab. Jurnal Paradikma, 5 (1): 2-19.

Tafsir, A. 2012. Konsep Pendidikan Karakter dalam Perspektif Islam, Jurnalel-Hikmah Fakultas Tarbiyah UIN Malang, 5(2): 139-154.

Undang-Undang Republik Indonesia Nomor 20 Tahun 2003.Sistem Pendidikan Nasional.

Wardani, E. K. and E. Widiyastuti. 2013. Mapping Wayang Tradisional Theatre as A Form of Local Wisdom of Surakarta Indonesia. Asian Journal of Social Science and Humanities, 2 (2): 314-321.

Wibowo, A. 2013. Pendidikan Karakter Berbasis Sastra. Yogyakarta: Pustaka Pelajar.

Zubaedi. 2011. Desain Pendidikan Karekter: Konsep dan Aplikasinya dalam Lembaga Pendidikan. Jakarta: Kencana 